\title{
Galanthus bursanus (Amaryllidaceae): a new species of snowdrop from the Marmara Sea region, NW Turkey
}

\author{
Dimitri A. Zubov ${ }^{1}$, Yıldiz Konca ${ }^{2}$ \& Aaron P. Davis ${ }^{3}$ (I)
}

Summary. Galanthus bursanus (Amaryllidaceae), a new snowdrop species endemic to the Marmara Sea region (Bursa Province, NW Turkey), is described and illustrated. Morphological differences between the new species and other possibly related Galanthus taxa (G. plicatus subsp. byzantinus, G. xvalentinei nothosubsp. subplicatus, and G. reginae-olgae subsp. reginae-olgae) are discussed. Photographs (habitat and morphology), a distribution map and a preliminary conservation assessment are provided.

Key Words. Calciphile, conservation, geophyte, hysteranthous, Turkish flora.

\section{Introduction}

The Marmara Sea region in north-western Turkey (Asian and European parts) is an area of high diversity for Galanthus, with five indigenous taxa: G. gracilis Čelak., G. plicatus M.Bieb. subsp. plicatus, G. plicatus subsp. byzantinus (Baker) D.A.Webb, G. trojanus A.P.Davis \& Özhatay and G. ×valentinei Beck nothosubsp. subplicatus (Zeybek) A.P.Davis (Zeybek \& Sauer 1995; Davis 1999; Davis 2001; Davis et al. 2001; Davis \& Özhatay 2001; Taşcı Margoz et al. 2013). According to the work of Rønsted et al. (2013) these taxa belong to three different phylogenetic clades: Trojanus ( $G$. trojanus), Nivalis ( $G$. plicatus and G. ×valentinei nothosubsp. subplicatus) and Elwesii (G. gracilis). All five taxa are synanthous (the leaves well-developed at the flowering stage (anthesis)) and have a winter - spring flowering period (Dec. - April).

In Nov. 2014, we (Konca \& Zubov, pers. obs.) discovered two small populations of Galanthus near the city of Bursa (Bursa Province) in the Marmara Sea region of NW Turkey, on the north-western spurs of Korucak Daği ridge. The plants were either leafless at flowering or leaves less than $3 \mathrm{~cm}$ long, mostly hidden under tree leaf litter, and the flowers were highly fragrant. Vegetative clones (clumping plants) were numerous, with many flower stalks in each clump (5 24). Both populations were located at an elevation of $500 \mathrm{~m}$, exclusively on rocky, limestone outcrops (but never on cliffs and rock walls), on red clay soil, in the semi-arid xerophytic dry oak forest phytocenosis of the Marmara Transitional region (Atalay et al. 2014), in which Quercus cerris L. (Turkey oak) acts as an indicator species (Fig. 2A - C). By their general appearance and period of flowering, the Galanthus at these two localities resembled G. reginae-olgae subsp. reginae-olgae, due to the partial development of leaves at flowering time (hysteranthous) and narrow leaf blades dark green but with a distinct glaucous central stripe, but clearly differed due to the presence of specific vegetative and floral characteristics (see RECOGNITION). Further investigation of the two subpopulations at a single location on Korucak Daği ridge showed that they possessed a combination of characters not found in any Galanthus from the Marmara Sea region, or indeed any other species in the genus. Given the distinct morphological characterisation, we hereby describe these plants as a new species of Galanthus: G. bursanus.

\section{Materials and Methods}

Field studies for Galanthus bursanus were undertaken in Turkey in 2014, 2016 - 2018 (Zubov \& Konca, pers. obs.), and seed grown living material in cultivation was examined by us between 2014 and 2018. Herbarium specimens of other Galanthus species were examined at the herbaria of K and KWHA (abbreviations after Holmgren et al. 1990). Measurements, colours, and other details are based on living material, spirit and herbarium specimens and data derived from field notes. Morphological and anatomical examinations were made using a stereo microscope Stemi 2000 - C and inverted microscope AxioObserver A1 equipped

\footnotetext{
Accepted for publication 12 March 2019. Published online 18 May 2019

1 State Institute of Genetic and Regenerative Medicine, National Academy of Medical Sciences of Ukraine, 67, Vyshgorodska str, Kyiv, 04114, Ukraine.

2 Mürsel mahallesi, Mehter caddesi, 1/2, Flora evleri, 16960, Mudanya-Bursa, Bursa Province, Turkey.

3 Royal Botanic Gardens, Kew, Richmond, Surrey, TW9 3AE, UK. e-mail: a.davis@kew.org
} 
with digital camera AxioCamERc 5s and ZEN 2012 software (Carl Zeiss, Germany). Morphological terminology follows Beentje (2010). Distribution maps were plotted using specimens and recorded coordinates, verified using Google Earth Pro (@2017 Google). The distribution map (Map 1) was produced using SimpleMappr (Shorthouse 2010). The preliminary conservation status of $G$. bursanus was informally assessed following the criteria and categories of IUCN's Red List Categories and Criteria (IUCN 2017).

Method for estimating AOO. Area of occupancy was calculated directly at the reference scale of $4 \mathrm{~km}^{2}$ (2 $\times$ $2 \mathrm{~km}$ ) grid cells by counting the number of occupied cells in a uniform grid that covers the entire range of a considered taxon, and then tallying the total area of all occupied cells: AOO $=$ no. occupied cells $\times$ area of an individual cell (IUCN 2017). For Galanthus bursanus $\mathrm{AOO}=2 \times 4=8 \mathrm{~km}^{2}$.

Galanthus bursanus Zubov, Konca $\mathcal{E}^{\circ}$ A.P.Davis sp. nov. Type: Turkey, Bursa Province, Marmara Sea region, limestone rocky outcrops near Bursa, c. 500 m, fl., 26 Nov. 2016, Zubov E Konca s.n. (holotype KWHA!).

http:/ /www.ipni.org/urn:lsid:ipni.org:names:60478400-2

Bulb narrowly ovoid to ovoid, $2.2-3.5(-4.5) \times(1.1-)$ $1.4-2(-2.5) \mathrm{cm}$, bulb scales whitish, bulb fully covered with a light brown to straw brown papery tunic; adventitious roots whitish. Basal sheath \pm tubular, tubular-conical, circular or oval in cross section, (1.2-) $3.1-6$ $\times 0.3-0.7 \mathrm{~cm}$, noticeably veined, slightly inflated, whitish to greenish (especially the upper part). Leaves hysteranthous, applanate (more precisely applanatenarrowly explicative) in vernation, at flowering time (anthesis) either absent or $1.8-3.1 \mathrm{~cm}$ long, developing in length and width after flowering; leaf blades narrowly linear to linear (strap-shaped), indistinctly canaliculate at early stage, slightly twisted, at maturity (10 -) $21-32 \times$ $(0.4-) 0.6-0.9(-1.4) \mathrm{cm}$, bearing 2 noticeable longitudinal folds, each $1-2 \mathrm{~mm}$ from (and parallel to) the margin (leaf margin narrowly explicative), the folds diminishing terminally and then the margin subrevolute to flat; abaxial surface with a prominent keel, dark green base-colour, with glaucous (wax) covering on both surfaces (grey to bluish grey), matt, with greener margins adaxially (i.e. dark green with a broad central glaucous stripe); apex obtuse, flat, with a small white point at tip. Scape 2 , rarely 1 or 3 , (7-) $10-18$ $(-25) \mathrm{cm}$ long, $1.7-3 \mathrm{~mm}$ in diam., light green, dark green in upper part, glaucous. Pedicel $1.2-4.2 \mathrm{~cm}$ long, 1 $-2 \mathrm{~mm}$ in diam., light green. Spathe papery, slightly arcuate, with 2 thick ribs (up to $1.5 \mathrm{~mm}$ in diam.) on margins, $22-45 \times 4-7 \mathrm{~mm}, \pm$ equal in length to the pedicel at flowering, dark green, glaucous. Flowers narrowly ovoid to pyriform when closed (i.e. in outline shape), strongly fragrant; perianth segments 6 , separated, in two whorls; outer perianth segments 3, narrowly obovate to obovate, indistinctly ribbed, $26-34 \times 9-13$ $\mathrm{mm}$, white, base unguiculate, claw $3-7 \times 2-4 \mathrm{~mm}$; apex acute, slightly cucullate; inner perianth segments $3, \pm 1 / 2$ the size of the outer perianth segments, broadly to narrowly obovoid to obtriangular, white, each segment with an apical sinus (notch) and two green marks, one apical and one basal, or one entire abaxial bold $\mathrm{X}$ shaped mark; on the abaxial surface, the apical mark $\Lambda$ -

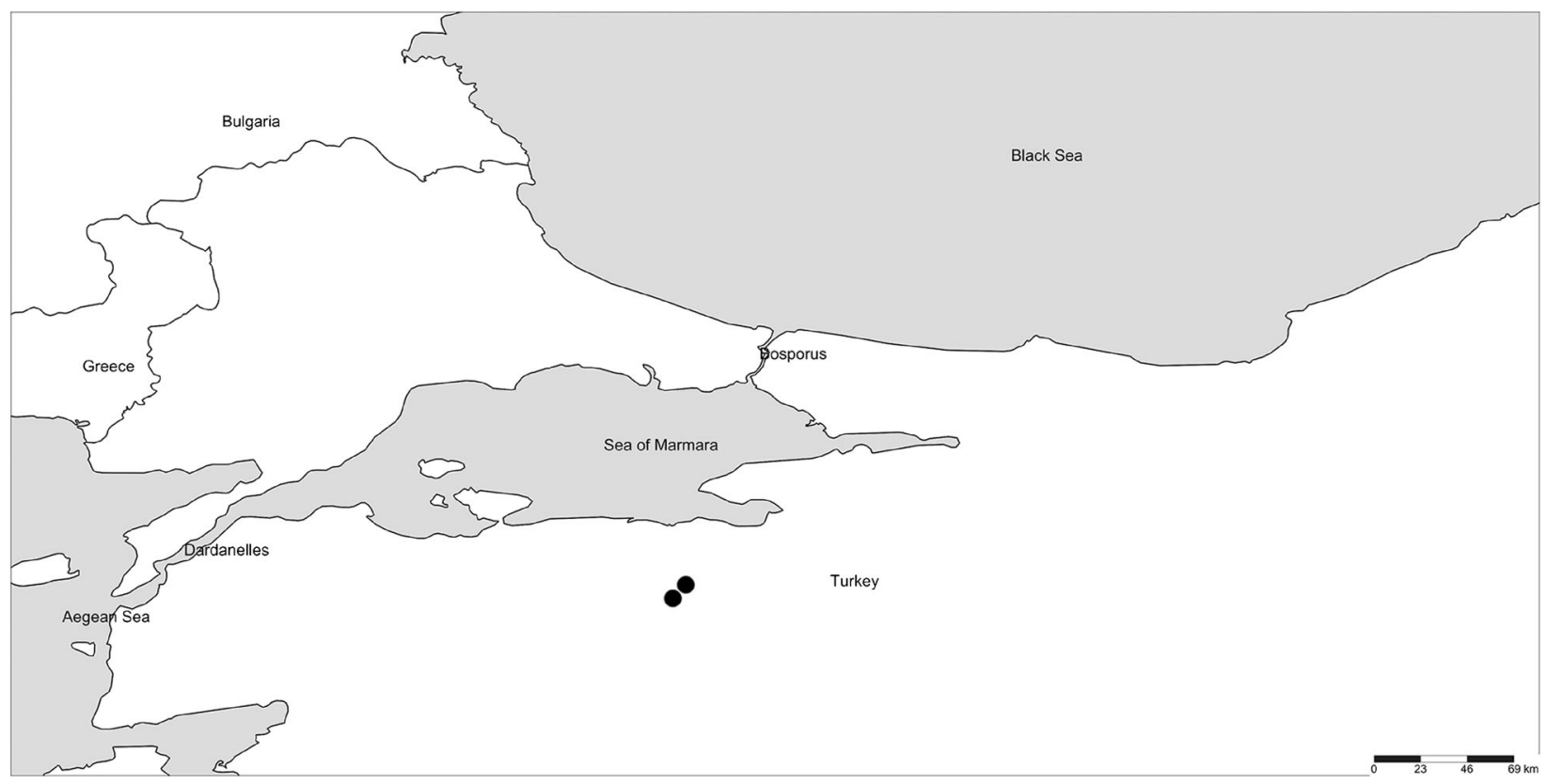

Map 1. Distribution of Galanthus bursanus based on collection localities. 
shaped, often narrower above the sinus, mostly looking like two fused (rarely non fused) commas; the margins near sinus curled upwards (flared); the basal mark mostly trapezoidal and indistinctly notched in upper and lower areas, rarely obovoid or like two fused narrowly obovoid or oblong strips, bold near the base, or separated from the receptacle by a $2-3 \mathrm{~mm}$ white gap and covering up to slightly more than half of the segment, $9-15 \times 5-9 \mathrm{~mm}$; adaxial surface with $3-4$ coaxial green lines, forming blurred apical and basal marks, and interspaced with a central white groove and 3-4 white coaxial grooves at the margins; stamens 6 , in two whorls; anthers basifixed, \pm sagittate, orange, connective c. $2.5 \times 0.6 \mathrm{~mm}$, anther sacs 4 per anther, c. $6 \mathrm{~mm}$ long and c. $1.2 \mathrm{~mm}$ in diam., latrorse in the middle part and introrse to the apex; anther apex sharply acute with multiple villi; filaments c. $2 \mathrm{~mm}$ long, white; pollen orange, microsporangia \pm oval, with lipid drops in exine, c. $35 \times 25 \mu \mathrm{m}$. Gynoecium (ovary and receptacle) syncarpous, tricarpellate; ovary superior, globose, or ellipsoid to narrowly ellipsoid, indistinctly triangular in cross section, bright green, 4-12 mm long, $3-8 \mathrm{~mm}$ in diam.; placentation axile, ovules $12-18$ per locule; pistil filiform, style $7-10 \mathrm{~mm}$ long and $0.3 \mathrm{~mm}$ in diam., greenish, with numerous villi (c. $0.4 \mathrm{~mm}$ long) in the upper $1 / 2-1 / 3$; stigma capitate, trilobed, c. $0.3 \mathrm{~mm}$ in diam. Fruit (capsule) at maturity indistinctly triangular in cross section, globose to ellipsoid, or narrowly ellipsoid, at maturity $0.9-1.7(-2.3) \times 0.6-1.5 \mathrm{~cm}$, bright to light green; seeds \pm orbicular to ovoid, $3-4.5 \times 2-3 \mathrm{~mm}$, with shiny light to dark brown reticulate seed coat and \pm developed whitish elaiosome (myrmecochory), 1 $3.5 \mathrm{~mm}$ long. Figs 1, 2 and 3.

RECOGNITION. Possibly related to Galanthus plicatus subsp. byzantinus and $G$. xvalentinei nothosubsp. subplicatus but differs by having hysteranthous leaves (vs synanthous in G. plicatus subsp. byzantinus and G. ×valentinei nothosubsp. subplicatus); and Oct. - Jan. flowering period (vs Dec. - April). Related possibly to G. reginae-olgae subsp. reginae-olgae but differs by the inner perianth segment carrying an apical and a basal mark, which infrequently merge into a single, bold, X-shaped mark (vs inner perianth segment only has one apical mark in G. reginae-olgae subsp. reginae-olgae). (see NOTES). DISTRIBUtION. Asia Minor: Turkey, Marmara Transitional region (north-western spurs of Korucak Daği ridge); a narrow local endemic of the Marmara Sea region. Map 1.

SPECIMENS EXAMINED. TURKey. Bursa Province, Marmara Sea region, limestone rocky outcrops near Bursa, c. 500 m, fl., 26 Nov. 2016, Zubov Eॄ Konca (holotype KWHA!); ibid., cult. (specimens grown from seeds in UK), fl., 6 Oct. 2017, Zubov $\mathcal{E}^{\mathcal{F}}$ Konca s.n. (K!). The exact localities of Galanthus bursanus have not been documented here for fear of unlawful plant collecting. HABITAT. Described from Quercus cerris forest at c. 500 $\mathrm{m}$ elevation; growing in red clay soils on limestone rocky outcrops around the city of Bursa. Mesophyte, calciphile. Phytocenosis indicators observed in the understory included the woody species $Q$. coccifera L., Crataegus monogyna Jacq., Acer monspessulanum L., Phillyrea latifolia L. and Ruscus aculeatus L.; and the herbaceous species Paeonia peregrina Mill., Fritillaria pontica Wahlenb., and Helleborus orientalis Lam.

CONSERVATION STATUS. Galanthus bursanus is endemic to northwestern Turkey, and is restricted to the Bursa Province. Its area of occupancy (AOO) is provisionally estimated to be less than $10 \mathrm{~km}^{2}$, and there are two known severely fragmented subpopulations. The habitat could decline rapidly due to deforestation and agricultural conversion of suitable habitat to crop land, although the rocky limestone outcrops where this species occurs offer some protection; marble mining occurs in the area and would influence subpopulations in sites corresponding to this species habitat; there is also the threat of small-scale collection of bulbs by illegal collectors, and this could cause a slow, long-term decline. This species is also deemed to be climate change sensitive. Due to the limited AOO, severely fragmented subpopulations and the range of threats, this species is assessed as Critically Endangered (CR) under IUCN Red List Categories and Criteria (IUCN 2017). CR B2ab(ii,iii): B2 - Geographic coverage in the form of AOO estimated to be less than $10 \mathrm{~km}^{2}$ threshold (AOO for G. bursanus is estimated to be $8 \mathrm{~km}^{2}$ ) and - a. Severely fragmented or known to exist at only a single location ( $G$. bursanus is known from only two severely fragmented subpopulations (based on two geolocated data points) at a single location); and - b. Continued decline observed (Map 1).

PHENOLOGY. Flowering: Oct. - Jan. (Feb.) in the wild; late Sept. - Dec. in cultivation; fruiting (wild and cultivated): April. In February, plants observed in situ were in the early fruiting stage and with considerably developed fruit, although about one-sixth of the population was at the very end of flowering. The northern spurs of Korucak Daği normally have significant snow cover from Dec. to early Feb.

ETYMOLOGY. Named after the Marmara Sea region Turkish Province - Bursa.

NOTES. Three Galanthus taxa from the Nivalis clade (Rønsted et al. 2013) have morphological affinities with $G$. bursanus: the broadly sympatric $G$. plicatus subsp. byzantinus (Davis 1999; Davis 2001) and G. xvalentinei Beck nothosubsp. subplicatus (Davis et al. 2001; Tasscı Margoz et al. 2013); and allopatric G. reginae-olgae subsp. reginae-olgae (Davis 1999; Davis 2001).

Galanthus plicatus subsp. byzantinus is broadly sympatric with G. bursanus (e.g. in Bursa and neighboring Yalova Provinces) and both taxa have an apical and basal, or sometimes large, bold, X-shaped mark on each inner perianth segment (Fig. 2D). However, unlike G. bursanus, G. plicatus subsp. byzantinus (and G. plicatus subsp. plicatus) are winter flowering, with 

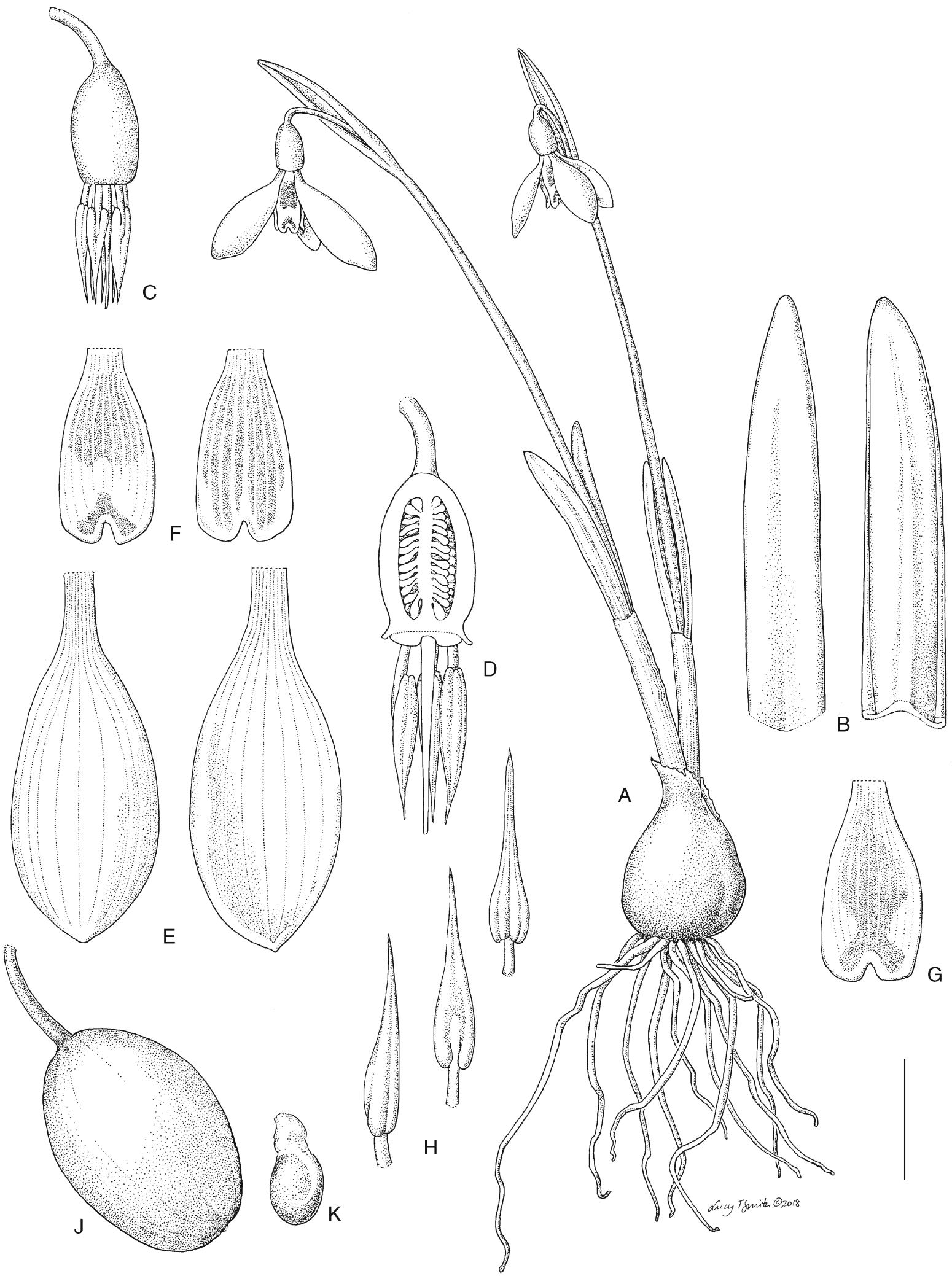

Fig. 1. Galanthus bursanus. A habit; B leaf (adaxial view (left) and adaxial view (right)), as cut from basal sheath; C flower with segments removed; D flower with segments removed in L.S.; E outer perianth segment (abaxial view (left) and adaxial view (right)); $\mathrm{F}$ inner perianth segment (abaxial view (left) and adaxial view (right)); $\mathrm{G}$ inner perianth segment (abaxial view), showing X-shaped marked variant; $\mathrm{H}$ anthers, showing side, abaxial and adaxial views (from lower to upper); J fruit (capsule) (including ovary); $\mathrm{K}$ seed. Scale bar: $A=2 \mathrm{~cm} ; \mathrm{B}, \mathrm{C}=7 \mathrm{~mm} ; \mathrm{D}-\mathrm{G}=8 \mathrm{~mm} ; \mathrm{H}=4 \mathrm{~mm} ; \mathrm{J}, \mathrm{K}=1 \mathrm{~cm}$. All from Zubov \& Konca s.n. DRAWN BY LUCY T. SMith. 

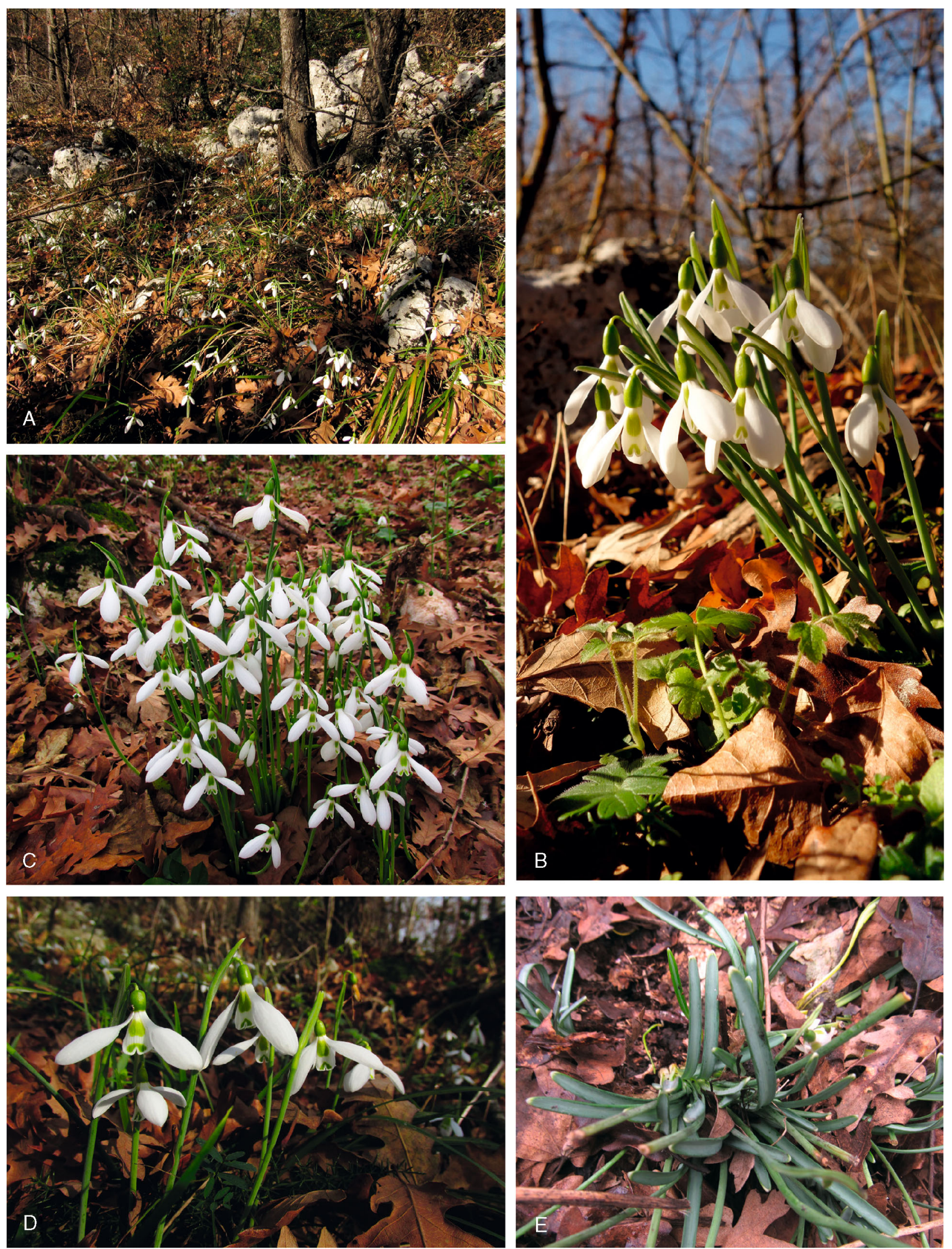

Fig. 2. Images of Galanthus bursanus in situ. A habitat, at red soil pockets developed in limestone outcrops under Quercus cerris forest; B, C habitat at locus classicus; D flowers; E leaves at fruiting stage. All photos taken at the locus classicus (A, B 26 Nov. 2016; C, D 25 Nov. 2018; E 11 Feb. 2017). PHOTOS: A, C - E D. ZUBOV AND B Y. KONCA. 


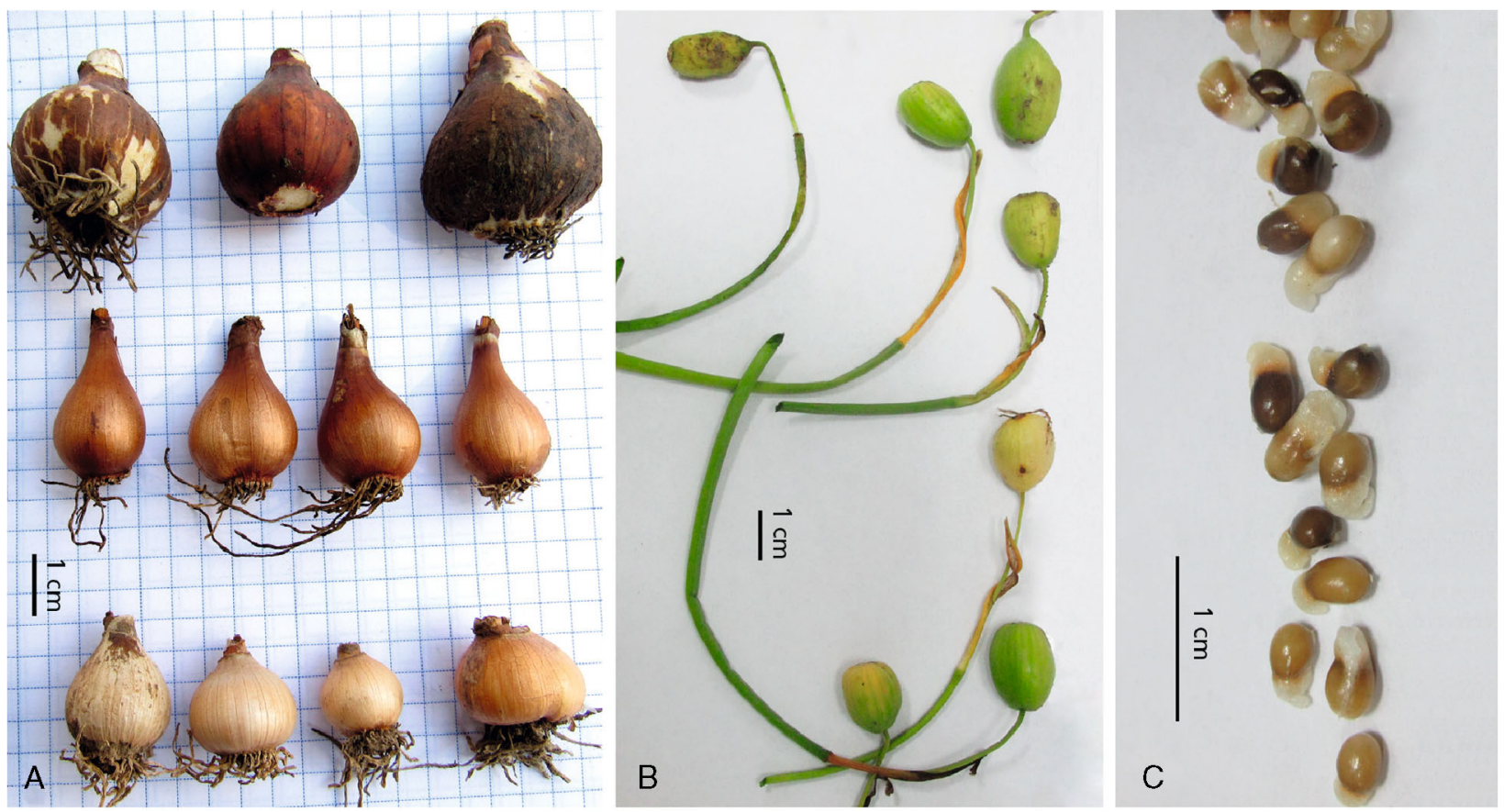

Fig. 3. Morphological features of Galanthus bursanus. A dormant bulbs (seed grown) - top row G. plicatus subsp. plicatus (Chatyrdag, Crimea, Ukraine), middle row G. bursanus, ex locus classicus, bottom row G. plicatus subsp. byzantinus (Polonezköy Ormani forest, Istanbul (Asian part), Turkey); B mature seed pods of G. bursanus; C mature seeds of G. bursanus. PHOTOS: D. zUBov.

flowers from Feb. - April (Davis 1999; Davis 2001), or sometimes earlier (Dec. or Jan.); have leaves that are well developed at flowering (synanthous), and leaf blades lanceolate to broadly lanceolate, with a prominent longitudinal fold $2-7 \mathrm{~mm}$ from each margin (explicative ['plicate'] vernation). Galanthus bursanus is autumn to early winter flowering, with flowers from Oct. - Jan.; has leaves that are either absent or poorly developed at flowering (hysteranthous), and leaf blades narrowly linear to linear, with a rather sharp longitudinal fold $1-2 \mathrm{~mm}$ from each margin (applanate, or more precisely applanate-subrevolute, weakly explicative) (Fig. 2E). Distinctly synanthous (flowering) representatives of G. plicatus subsp. byzantinus were discovered by us (Zubov \& Konca, pers. obs.) in Feb. 2017, in the river canyon to the north-east of Bursa (southern spurs of Katirli Dağlari ridge). In this locality these populations were found in small Pinus brutia Ten. woodlands, the plants growing in small numbers on a limestone scree (in brown forest soil) and on a flat, north-west facing cliff along the bottom of the narrow canyon. In the neighboring Yalova Province (visited by us in Nov. 2018, Zubov \& Konca, pers. obs.) synanthous G. plicatus subsp. byzantinus is exclusively confined to the Fagus orientalis Lipsky forests at c. $600 \mathrm{~m}$, within the northern spurs of Samanli Dağlari ridge and flower there early Dec. Feb. All of the plants in these populations possessed leaves typical of the species.

Galanthus xvalentinei nothosubsp. subplicatus is a hybrid taxon believed to be the result of introgression between G. nivalis L. and G. plicatus subsp. byzantinus (Davis et al. 2001; Rønsted et al. 2013). This taxon is not narrowly sympatric with $G$. bursanus but it does occur in the Marmara Sea region, including the part of Turkey in Istanbul (in Europe), Kirkareli and Edirne Provinces and it shares some characteristics with the new species. Like G. bursanus, G. xvalentinei nothosubsp. subplicatus has linear leaf blades, and the leaves can be weakly explicative (on the same leaf, same plant, or plants may differ; some leaves with flat-subrevolute margins), and although there is usually only one mark on each inner perianth segment it may sometimes have one or two small, faint marks at the base of the segment (i.e. approaching a basal mark) (Davis et al. 2001). Galanthus xvalentinei nothosubsp. subplicatus differs further from G. bursanus by its flowering period (Jan. - March vs Oct. to Jan.), synanthous leaves (vs hysteranthous) and by leaf colour, which is glaucescent (green with a slight glaucous bloom) to almost glaucous on the adaxial surface and green-glaucescent to glaucescent on the abaxial surface (Davis et al. 2001) (vs dark green with a central, broad glaucous stripe (Fig. 2E)).

The leaf folding in Galanthus bursanus, which is applanate-narrowly explicative in vernation (i.e. the position of the leaves in bud, as viewed in transverse section (T.S.), with narrowly explicative leaf margins (folded sharply towards the abaxial surface) at maturity, is similar, although more pronounced than the hybrid G. xvalentinei nothosubsp. subplicatus. Morphological investigations suggest that the parentage of G. xvalentinei nothosubsp. subplicatus involves 
G. plicatus subsp. byzantinus and G. nivalis (Davis et al. 2001). Molecular data (Rønsted et al. 2013; Taşcı Margoz et al. 2013) support the assumption of hybrid origin for $G$. xvalentinei nothosubsp. subplicatus (Davis et al. 2001), although the exact parentage is not yet known; the most detailed molecular study so far (Rønsted et al. 2013) infers introgression between G. plicatus s.l. and a member of the Nivalis clade. On this basis, it is possible that $G$. bursanus could be a species of hybrid origin, most likely involving G. plicatus subsp. byzantinus. Molecular data would be required to elucidate a possible hybrid origin.

The leaves of both Galanthus reginae-olgae subsp. reginae-olgae and G. bursanus are hysteranthous, i.e. they are either absent or only partially developed (e.g. only a few cms long) at flowering time (anthesis), and both taxa flower in the autumn (Sept. - Dec. for the former, and Oct. - Jan. for the latter). The other subspecies of Galanthus reginae-olgae subsp. vernalis, has synanthous leaves, i.e. fully developed, or more less so, at flowering time, and flowers in the spring (Jan. - March) (Davis 1999, 2001). The leaf blades of $G$. reginae-olgae subsp. reginae-olgae (and subsp. vernalis) are narrow (narrowly linear to linear (strap-shaped)), and dark green with a glaucous covering (mostly confined to the centre of the leaf and thus often described as a central stripe). Despite sharing characters, there are clear differences between these taxa: the leaves of $G$. reginae-olgae are never longitudinally folded (see below) but are flat (not folded) with either flat or subrevolute margins, and each inner perianth segment only has one apical mark. In G. bursanus the leaf blades have longitudinal folds either side of the midrib and each inner perianth segment carries an apical and a basal mark, which infrequently merge into a single, bold, X-shaped mark (Fig. 2D, E). The present-day distributions of $G$. bursanus and $G$. reginae-olgae are separated by a considerable distance, the latter occurring in southern Italy, Sicily, western and southern Greece, Albania and possibly Montenegro (Davis 1999, 2001).

Sympatric Galanthus gracilis intersects mosaically with $G$. bursanus on the northern spurs of Korucak Daği, and this region also inhabits the southeastern shore of Ulubat Gölü lake. The valley of the Nilüfer Çayi river (which flows latitudinally, enters Susurluk Cayı river and descends to the Marmara Sea) can be considered to form a natural watershed between the populations of G. plicatus subsp. byzantinus in the north and the populations of $G$. gracilis and $G$. bursanus in the south. Galanthus gracilis does not share obvious morphological affinities with G. bursanus.

The recently described Galanthus samothracicus Kit Tan \& Biel (Biel \& Tan 2013; Tan et al. 2014) from the island of Samothraki (N Aegean, NE Greece) does not have any conspicuous morphological affinities with allopatric G. bursanus, having synanthous leaves, dull green leaves, with flat-subrevolute margins and a single green, apical mark on each inner perianth segment.

\section{Key to the identification of G. bursanus, G. plicatus, G. reginae-olgae and G. xvalentinei nothosubsp. subplicatus}

1. Leaves absent or $<3 \mathrm{~cm}$ long at flowering time (hysteranthous); flowering Sept. - Jan . . . . . . . . . 2

1. Leaves present and well developed at flowering time (synanthous); flowering Dec. - March . . . . . . . 3

2. Leaf blade margins each with 2 sharp longitudinal folds $1-2 \mathrm{~mm}$ from the leaf margin (margins narrowly explicative-subrevolute); each inner perianth segment with two distinct green marks, one at the apex and one at the base, or one large, more or less X-shaped green mark; flowering Oct. - Jan.; NW Turkey . . . . G. bursanus

2. Leaf blades margin flat to subrevolute; each inner perianth segment with a single, green apical mark; flowering Sept. - Dec.; Italy, Sicily, Greece, and possibly Albania . . . . . . . . . . G. reginae-olgae subsp. reginae-olgae

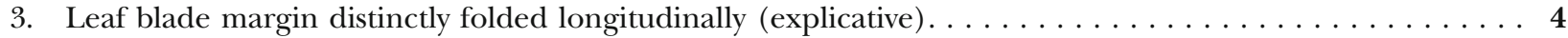

3. Leaf blade margin flat to subrevolute, or narrowly explicative-subrevolute. . . . . . . . . . . . . 5

4. Inner perianth segments with one green mark at the apex. . . . . . . . . . G. plicatus subsp. plicatus

4. Inner perianth segments with one green mark at the apex and one distinct green mark at the base . . . . . $\ldots \ldots \ldots \ldots \ldots \ldots \ldots \ldots \ldots \ldots \ldots \ldots \ldots \ldots$. plicatus subsp. byzantinus

5. Leaf margins flat to subrevolute; inner perianth segments with one green mark at the apex . . . . . . . .

G. reginae-olgae subsp. vernalis

5. Leaf margins weakly to conspicuously explicative-subrevolute; inner perianth segments with one green mark at the apex and often one sometimes with two faint marks at the base . . . . . . G. xvalentinei nothosubsp. subplicatus

\section{Acknowledgements}

The authors would like to thank Serge Hončar, Nihat and Kivilcim Konca for the field work technical assistance for D. Zubov and Y. Konca, and Lucy T. Smith for her drawing of Galanthus bursanus.
Open Access This article is distributed under the terms of the Creative Commons Attribution 4.0 International License (http://creativecommons.org/ licenses/by/4.0/), which permits unrestricted use, distribution, and reproduction in any medium, provided you give appropriate credit to the original 
author(s) and the source, provide a link to the Creative Commons license, and indicate if changes were made.

\section{References}

Atalay, I., Efe, R. \& Ozturk, M. (2014). Ecology and classification of forests in Turkey. Procedia Soc. Behav. Sci. 120: 788 - 805.

Beentje, H. (2010). The Kew Plant Glossary. An illustrated dictionary of plants terms. Kew Publishing, Richmond.

Biel, B. \& Tan, K. (2013). Reports 16 - 24. In: V. Vladimirov et al. (comp.), New floristic records in the Balkans: 23. Phytologia Balcan. 19 (3): 375 - 378.

Davis, A. P. (1999). The Genus Galanthus. Timber Press, Portland, Oregon, in association with the Royal Botanic Gardens, Kew. (2001). The genus Galanthus - snowdrops in the wild. In: M. Bishop, A. P. Davis \& J. Grimshaw (eds), Snowdrops: a monograph of cultivated Galanthus, pp. 9 - 63. Griffin Press, Maidenhead.

\& Özhatay, N. (2001). Galanthus trojanus: a new species of Galanthus (Amaryllidaceae) from northwestern Turkey. Bot. J. Linn. Soc. 137: 409 - 412.

, Byfield, A., Özhatay, N. \& Taylor, K. (2001).

Galanthus ×valentinei nothosubsp. subplicatus (Amaryllidaceae): a new hybrid Galanthus from north-western Turkey. Kew Bull. 56: 639 - 647.

Holmgren, P. K., Holmgren, N. H. \& Barnett, L. C. (1990). Index herbariorum. Part 1: the herbaria of the world, 8th edn. Regnum Veg. 120. New York Botanical Garden, New York.
IUCN (2017). IUCN Standards and Petitions Subcommittee, Guidelines for using the IUCN Red List Categories and Criteria. Version 13. Prepared by the Standards and Petitions Subcommittee. http://www.iucnredlist.org/documents/RedListGuidelines.pdf.

Rønsted, N., Zubov, D. A., Bruun-Lund, S. \& Davis, A. P. (2013). Snowdrops falling slowly into place: an improved phylogeny for Galanthus (Amaryllidaceae). Molec. Phylogen. Evol. 69: 205 - 217.

Shorthouse, D. P. (2010). SimpleMappr, an online tool to produce publication-quality point maps. [Retrieved from http:/ /www.simplemappr.net. Accessed 2017-10-04].

Tan, K., Biel, B. \& Siljak-Yakovlev, S. (2014). Galanthus samothracicus (Amaryllidaceae) from the island of Samothraki, northeastern Greece. Phytologia Balcan. 20: $65-70$.

Taşcı Margoz, N., Yüzbaşioğlu, I. S., Çelen, Z., Ekim, T. \& Bilgin, A. N. (2013). Molecular phylogeny of Galanthus (Amaryllidaceae) of Anatolia inferred from multiple nuclear and chloroplast DNA regions. Turkish J. Bot. 37: 993 - 1007.

Zeybek, N. \& Sauer, E. (1995). Türkiyer Kardelenleri (Galanthus L.) I. / Beitrag Zur Kenntnis Der Türkischen Schneeglöckhen (Galanthus L.) I. - VSB Altinova-Karamürsel. [In Turkish and German].

\section{Publisher's Note}

Springer Nature remains neutral with regard to jurisdictional claims in published maps and institutional affiliations. 